Document downloaded from:

http://hdl.handle.net/10251/61572

This paper must be cited as:

López Estornell, M.; Barberá Tomás, JD.; Garcia Reche, A.; Mas Verdú, F. (2013). Evolution of innovation policy in Emilia-Romagna and Valencia: Similar reality, similar results?. European Planning Studies. 22(11):2287-2304. doi:10.1080/09654313.2013.831398

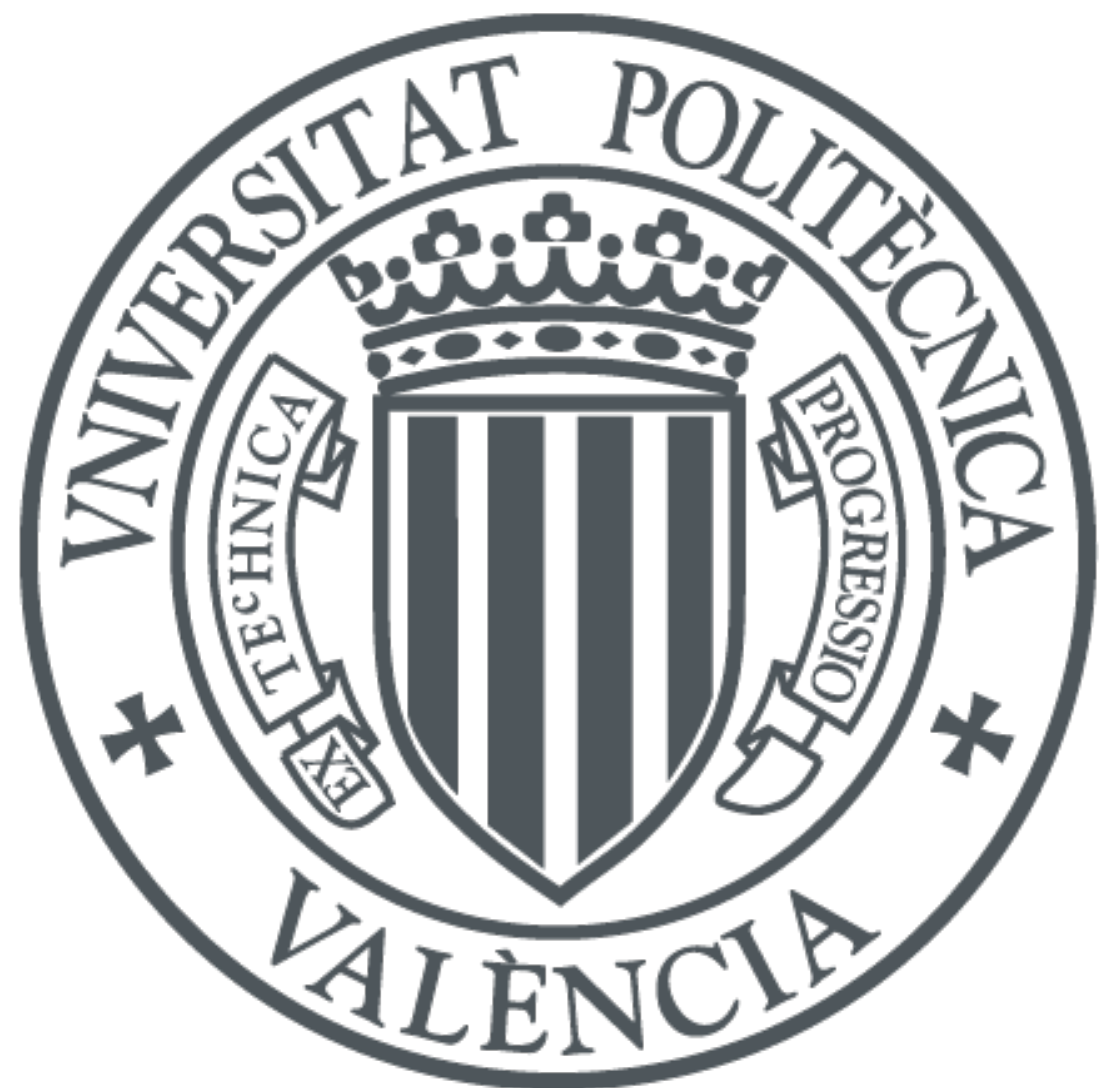

The final publication is available at

http://dx.doi.org/10.1080/09654313.2013.831398

Copyright Taylor \& Francis (Routledge): SSH Titles

Additional Information

This is an author's accepted manuscript of an article published in:

"European Planning Studies"; Volume 22, Issue 11, 2014; copyright Taylor \& Francis; available online at: http://dx.doi.org/10.1080/09654313.2013.831398 


\title{
Evolution Of Innovation Policy In Emilia- Romagna And Valencia: Similar Reality, Similar Results?
}

\author{
Manuel López-Estornell ${ }^{\mathrm{a} 1}$, David Barberá-Tomás ${ }^{\mathrm{a}}$, Andrés García-Reche ${ }^{\mathrm{b}}$, \\ Francisco Mas-Verdúc \\ a INGENIO (CSIC-UPV), Universitat Politècnica de València, Camino de Vera s/n \\ 46022 Valencia, Spain. Tel. 34+96.387.70.48. \\ ${ }^{\mathrm{b}}$ Universitat de València, Departamento de Economía Aplicada. \\ ${ }^{\mathrm{c}}$ Universitat Politècnica de València, Departamento de Economía y Ciencias Sociales.
}

Keywords: innovation policy; industrial district; Emilia-Romagna; Valencia

\begin{abstract}
This paper examines the evolution of regional innovation policy in EmiliaRomagna, and Valencia, regions with similar economic features that implemented similar innovation policies in the 1970s and 1980s. We investigate whether their similarities have led to similar targets, policy tools and governance developments. We show that innovation policy in both regions suffered from the effects of privatization, budget constraints and changes to manufacturing during the 1990s and highlight the consequences. Although Emilia-Romagna experienced deeper change to its innovation policy, privatizations and/or the replacement of public funds promoted commercial approaches and induced market failures in both regions. The worst effects of these policies were the implementation of less risky innovation projects, the shift towards extra-regional projects and markets, and the favouring of large firms.
\end{abstract}

${ }^{1}$ malopes@ingenio.upv.es 


\section{Introduction}

This paper examines the evolution of regional innovation policy in Emilia-Romagna, and Valencia, which have similar economic features and which implemented similar industry policies in the 1970s and 1980s. These policies were related to innovation and linked to the respective territories. The originality and positive consequences of these region's industry policies has attracted research interest focusing especially on the role of the regional agencies ERVET (Emilia-Romagna) and IMPIVA (Valencia) as flagship organizations. In 1982, the 'Emilian model' (Brusco, 1982), was well known in research on design (Brusco, 1992) and implementation of industry policy aimed at small and medium-sized enterprises (SME) (Brusco, 1989; Bellini, Giordani \& Pasquini, 1990; Bianchi \& Giordani, 1993; Bellini, Mohammad-Saïd \&Négrier, 1996; Petrakos, 1996; Cowell, 2010; López-Estornell, Mas-Verdú \& Molina-Morales, 2008), trade union participation in regional economic development (Sleigh, 1993) and evolution of the policy model (Cooke, 1996; Bellini \& Pasquini 1998; Bianchi, 1998; Amin, 1999; Rinaldi, 2005; Bianchi \& Sandrine, 2011). Several scholars have written about ERVET and other examples of regional development agencies in Italy, for example, Bianchi (1992), Bianchi \& Pasquini (1998), Belussi (1999), Pietrobelli \& Rabelloti (2002), Solari (2004) and Maccani \& Samoggia (2010), as well as on real service centres (RSC), for example, Brusco (1992) and Bellini (1996).

IMPIVA has been investigated by Ors (1994), Salom-Carrasco (1997), Ponce (2004) and Muñoz (2009) while its network of Technology Institutes (TI) ${ }^{2}$ has attracted the interest of other scholars (Esteve, Martínez-Serrano \& Picazo, 2000; Albors-Garrigós, Segarra \& Rincó-Díaz , 2010; García-Reche, 2003). The influence of AIJU, the Valencia’s TI

\footnotetext{
${ }^{2}$ Technology Institutes in Valencia and real service centres in Emilia-Romagna offer advanced services mainly to SME.
} 
related to toy firms is examined in Holmström (2006), the services provided by INESCOP to the shoe industry is investigated in Tomás, Contreras \& Del Saz (2000), the contribution to environmental services in tile industry by the IT of ceramics (ITC) is explained by García-Reche \& Picazo-Tadeo (2007) and the role played in textiles of Emilia-Romagna by CITER, a RSC linked to ERVET, is analysed in Bianchi (1995), Bianchi \& Bellini (1991, 1995) and Ligabue (1995), while García-Quevedo \& MasVerdú (2008) identify some economic variables that explain the use of the services provided by TI. Some authors study the relationship between use of TI and export activity (Mas-Verdú, Baviera-Puiga \& Martínez-Gómez, 2008), the efficacy of knowledge-intensive services (Martínez-Gómez, Baviera-Puiga \& Mas-Verdú, 2010) and the effect of the IMPIVA programmes on product quality (Moreno, 1993).

In addition to work that focuses on either Emilia-Romagna or Valencia, there are some comparative studies. Emilia-Romagna is contrasted with Baden-Württemberg (Heindereich, 1996; Cooke \& Morgan, 1994), and Denmark (Kristensen, 1992). IMPIVA has been compared with institutions in other regions and countries: see Barge-Gil \& Modrego (2007) for a study of TI in several regions of Spain, Holmstrom (1999) for India, Montero (2001) for Brazil, and Samoilovich et al. (2005) for France and Holland, among others. Some studies compare the cases of Emilia-Romagna and Valencia based on their similar economic, demographic and policy features. For example, LópezEstornell (2007) develops an extensive face-to-face between both regions and Ansell (2000) highlights the existence of networking. Mas-Verdú (2007) includes the two regions in a comparison that includes other European regions, and Fernández de Lucio, Rojo \& Castro (2003) analyses the characteristics of the two areas within a broader context. 
This article provides a comparative analysis of one aspect common to these two cases which has not previously been investigated: the evolution over time of their regional innovation policies and whether the regions' socioeconomics similarities have led to similar policy tool and governance trajectories.

We look at the implementation of advanced technological services through the introduction of RSC in Emilia-Romagna and IT in Valencia, and their effect on SME. We discuss the consequences for policy and firms of the privatizations that occurred in the regions analysed during the 1990s. Comparison of these two cases highlights the conditions needed for persistence (Hughes, 1936) in the institutional arrangements related to new policy, which require adaptation to changing environments and sufficient stability to ensure transformation (Steinberg, 2012). Comparison of the cases of Valencia and Emilia-Romagna will identify some of the factors related to the dynamic development of innovation service policies.

The paper is organized as follows. Section 2 presents the research methodology. Section 3 discusses similarities and differences between Emilia-Romagna and Valencia. Section 4 examines innovation policies related to advanced technological services for SME in the two regions. Section 5 summarizes the changes to innovation policy strategies and the effects of the pressures related to the privatization of service provision in Valencia and Emilia-Romagna. Section 6 offers some conclusions.

\section{Research methodology}

We chose a qualitative methodology. Information and data were collected using explorative methods. Semi-structured interviews were conducted with 15 individuals who were in positions of responsibility in regional governments and research institutions or were representatives of important firm support organizations (see Annex for list of 
interviewees). All interviews were conducted by a member of the research team. Interviewees were sent letters explaining the reasons for the research and topics that would be addressed in the interview. Interviewees were also able to expand on areas of the regional innovation policies.

We also administered a survey, that included questions related to innovation and cluster policy, which was addressed to 40 academics and experts on regional policy and local development, who had participated in the Annual Meeting held in Artimino, (24-26 September 2008) organized by the Research Institute Iris of Prato with the collaboration of University of Firenze. We achieved 15 completed surveys (almost 40\% response rate).

Secondary information and data were collected during the fieldwork period, from reports, documents, journals and the publications of private and public several institutions related to regional development and innovation policy in Valencia and Emilia-Romagna. Information was also collected from the publications of relevant support firm organizations in both regions. The region of Emilia Romagna has been studied in detail in the industrial district literature; the Valencian case has received less research attention and, therefore, is described in more detail here.

\section{Emilia-Romagna and Valencia: Main similarities and differences}

In the 20th century Emilia-Romagna and Valencia experienced some profound changes, including the transition from an agrarian to an industrial economy. In the first phases of the industrialization of these (and many other) regions, handicrafts were important. Both the regions analysed in this paper are specialized in traditional sectors including textiles and clothing, ceramics, furniture, footwear, and food products, although Emilia-Romagna 
also manufactures a wide array of machinery. In both regions innovation is mainly based on low level presence of in-house R\&D and intensive use of embodied technology.

\subsection{Some general features of the two regions}

Emilia-Romagna and Valencia are similar sized geographically, and have comparable population numbers (Table 1). Their respective economic nodes are along the Via Emilia and the Mediterranean Highway. Both regions are densely populated with their urban populations concentrated in the cities of Valencia (population 800,000) and Bologna (380,000). Per capita income is above the European average in Emilia Romagna, and slightly below it in Valencia.

\section{[Table 1 about here]}

\subsection{Economic similarities}

Valencia and Emilia Romagna have some similar economic features. For example, diversification of regional production, which has contributed to the achievement of balanced economies; highly export oriented manufacturing and agri-food industries; prevalence of SME - with especially intense development in the 1960s and 1970s; scarcity of state-owned enterprises; social recognition of entrepreneurial ventures; high density of firms (8.4 and 7 per 100 inhabitants in 2005 respectively); industry specialization above the national average; and predominantly traditional manufacturing sectors.

In 2003, manufacturing and services accounted for 367,112 firms in Emilia-Romagna and 299,452 firms in Valencia (which is $82 \%$ of the Emilia Romagna total). ${ }^{3}$ There are

\footnotetext{
3 Italian and Spanish statistics are calculated slightly differently, therefore, these figures should be interpreted with some caution.
} 
2,603 firms in Emilia-Romagna and 2,565 firms in Valencia with more than 50 employees; the numbers of firms employing 10 to 49 workers is similar in the two regions as well.

In both areas, manufacturing is organized mostly in clusters/industrial districts. Valencia has the highest number of manufacturing clusters in Spain (almost 50) (Boix \& Galletto, 2006a, 2006b), although many are very small in size. Its main areas of specialization are ceramic tiles (Castelló, Vila-real, Onda), furniture (Vinaròs, València), textiles and clothing (Alcoi, Ontinyent), and leather and footwear (Elx, Elda, Villena). EmiliaRomagna hosts several industrial districts or local production systems (LPS). Its industrial district specialization is very similar to cluster specialization in Valencia and includes ceramics (Sassuolo), textiles and clothing (Carpi) and footwear (S. Mauro Pascoli, Fusignano). However, Emilia-Romagna is also a specialist producer of motorcycles (Bologna) and food processing (Parma) (ERVET, 2002). Finally, both regions host important trade fairs (Valencia and Bologna), which are important for SME's export activities.

\subsection{Economic and political differences}

The major difference between the two regions is that Italy has been a democracy since the end of World War II, but Spain's democratic Constitution did not come to power until 1978. Also, Spain became a member of the European Common Market only in 1986, an important but belated development for Valencia, whose regional economy relies heavily on exporting. Spanish industrialization under Franco's regime was aligned to the establishment and support of large firms to achieve autarchy. National policy involved economic interventionism and trade protectionism both of which were damaging to export-oriented SME. 
Both regions have high concentrations of manufacturing SME, but some of their sectoral features differ. Emilia-Romagna has traditional manufacturing sectors, many of which are located along the Via Emilia, and a specialized, diffused machinery sector, which drives innovation in the region. ${ }^{4}$ In Valencia, specialization is mainly in traditional manufacturing, although since the 1970s, plastics, metals, chemicals and packaging sectors have become established. However, in contrast to the situation in EmiliaRomagna, there are no 'push’ sectors similar to machinery, to impel innovation. On the other hand, the Italian region holds a greater concentration of manufacturing and knowledge intensive business services (KIBS), and a smaller presence of construction/building and tourism sectors.

Valencia and Emilia-Romagna are both exporters: ratio of exports to regional added value was 31.4\% for Emilia-Romagna in 2004 and 23.5\% for Valencia in 2006. The comparative weakness of the Spanish region can be set against the effort invested in Emilia-Romagna to consolidate international distribution networks and to decentralize some phases of production.

The dominant political party governing Emilia Romagna up to the 1990s was the Italian Communist Party (PCI). ${ }^{5}$ It was anti-large firms (Brusco \& Pezzini, 1992), which it saw as a legacy of the fascist oligopolies. It was keen to forge strategic alliances with SME and to consider the big traditional companies as the common enemy. The PCI supported a competitive market as a means to stimulate SME growth and to reduce the market power of the large companies. This resulted in support for an industrial relations

\footnotetext{
${ }^{4}$ Emilia-Romagna also hosts automobile, motorcycle and biomedical firms.

${ }^{5}$ Since the early 1990s regional government has been dominated by centre-left coalitions.
} 
framework that favoured SME, and the implementation of policies designed to mitigate the financial and technological advantages of large firms.

In Valencia, political leadership between 1983 and 1995 was with the Socialist Party (PSOE-PSPV), with regional governments predisposed to agreements with unions and employers and generally to creating a climate of collaboration to overcome the difficult economic situation provoked by the oil crisis and political transition.

The powers of the two regional governments are different. The process of regionalization occurred first in Italy, but the level of responsibility and financial resources transferred by the Spanish government to the regions was higher in Spain. Regional public funding combined with EU and national funds enabled the development of strong industrial policy in Valencia. There is another difference that explains why the role of regional government is weaker in Emilia-Romagna, which is the strength of its local and provincial governments compared to those in the region of Valencia, where the regional government has experienced more support. Valencia has a smaller experience of infraregional government intervention in local economic development. Thus, industrial policy in Valencia had fewer reference points pre the process of devolution described in the Spanish Constitution and the Valencia Statute of Autonomy.

By contrast, the lower budget of regional government in Emilia-Romagna stimulated the greater regional coordination of industrial policy with other policies such as formal education and, especially, vocational training. The tradition of the-job-training in firms contributed to this target, although it was also influenced by the need for more skilled workers in the machinery sector and in sectors of the economy that depended on their leadership in quality, design and brand. 
Both regions also have different relationships with their respective central governments. In the case of Valencia, since 1983, it was only in 1995 and the period 2004 to 2011 that the parties in power were different, whereas in the case of Emilia-Romagna, from the introduction of its industrial policy in 1974, the politics of the national and regional governments have rarely coincided.

At the institutional level, the Italian and Spanish employers' associations also show some differences: pluralism and competition in the former case and practical monopoly of representation of employers in the latter. As a result of competition, the degree of association and the force exerted by business associations in providing services to their members are also different and more intense in Emilia-Romagna.

\section{Innovation policy in Emilia-Romagna and Valencia: implementation in the 1970 s and $1980 s$}

Innovation policy in Emilia-Romagna and Valencia can be described as pioneering in the regional context of the southern European countries (see references Section 1). Innovation policy started in Emilia-Romagna in the second half of the 1970s and in Valencia in 1983. In the first phase (1975-1990), innovation policy in Emilia-Romagna prioritized SME and the establishment of RSC as government's response to failures to provide specialized and innovative business services (Brusco \& Pezzini, 2008). The measures implemented represented political aims to support the position of the PCI, to develop alternative policies from those promoted by central government, which was controlled by the Christian Democrat Party, and to strengthen the weak regional institutions in a territory governed by powerful local authorities. In Valencia, the regional branch of the Socialist Party (PSPV-PSOE) was in power in 1983 to 1995. Its agenda included encouraging competition among manufacturing SME, which were experiencing 
productivity problems and high rates of unemployment. Regional policy included diversification of the economy and the maintenance of good relationships with the few big companies located in the region. The policy emphasis was on the so-called real or productive economy as opposed to speculative firms.

Industry policies in Valencia and Emilia-Romagna in the 1970s and 1980s implemented a wide range of tools, although in this paper we focus on a subset related to innovation. These policies gave support to individual firms outside of traditional industry policy which used to include award of grants, special rates for loans/investments and subsidies to reduce the cost of dismissing workers and focused sectoral policies. Instead, in the regions studied in this paper, the aim was to establish a new economic culture focused on firm innovation.

The Emilia-Romagna government agency, ERVET, ${ }^{6}$ was set up in 1974 to manage the ERVET-system, which comprised six sectoral service centres and three horizontal centres. It also promoted or participated in a financial support organization and several local development agencies (see Table 2). ERVET had a majority stake in the RSC, which it coordinated and supported financially, with the remaining shares belonging to business associations, municipalities and chambers of commerce.

\section{[Table 2 about here]}

In 1982 the Statute of Autonomy for the Valencian Region was approved. A year later, the first regional elections resulted in a majority for the Socialist Party of Valencia (PSPV-PSOE). The president of the new regional government, in his inaugural address, announced the creation of a regional institute for SME. A team of economists in the research bureau of the Valencia Chamber of Commerce had previously produced several,

\footnotetext{
${ }^{6}$ Emilia Romagna Valorizzazione Economica del Territorio (Economic Upgradings of Emilia Romagna’s Territory).
} 
sectoral focused studies of the Valencian economy (Rico, 1982). They identified a lack of innovation in the regional industry, lack of technical staff, weakness of the advanced tertiary sector, and territorial concentration of several major low to medium-low technology manufacturing sectors. They identified the Valencian industry as at risk from competition with more technologically advanced firms in developed countries and companies in developing countries that could compete on lower production costs.

The same team conducted analysis of industry policy in other European regions and countries, including Germany, the UK, the Nordic countries, the Basque Country and Italy, to highlight differences with the Valencian context. The situation in Valencia, thus, was not just a straight copying of the policy in place in Emilia-Romagna as some authors suggest (Cooke, 1996; Holmström, 2006). Nevertheless, Romano Prodi, a member of NOMISMA and founder of Rivista di Economia e Politica Industriale, in which he published several articles, had an intellectual influence.

This research bureau team of economists proposed the creation of a regional agency for industrial policy, IMPIVA, to regional government, and helped to draft the Act that resulted in its establishment in 1984. The members of the team constituted IMPIVA's first management directorate. The structural reasons behind the setting up of IMPIVA included the rapid technical evolution, the increased international competition on price, quality, diversity and design, and the competitive position of the Valencian economy between more advanced economies and low cost developing country firms. IMPIVA's main objectives were to promote cooperation among companies, to increase the provision of advanced business services, to improve productivity, to facilitate the introduction of more advanced technologies and new product development in firms, and to foster the use of industrial design tools. 
The agency's initial budget was only 200 million pesetas (about $€ 1.4$ million), which was an incentive the agency to search for additional sources of funding, such as the European Regional Development Fund (ERDF), in which the Valencian Region was part of Objective 1. European funds and Spanish government funds became a mainstay of the agency’s budget which multiplied sixfold (up to 1,200 million pesetas or $€ 14$ million).

The agency, in collaboration with business associations in various sectors, was responsible for $14 \mathrm{TI}$ in the mid-nineties. ${ }^{7}$ Most of these were new $\mathrm{TI}^{8}$, managed by professionals who were independent of the regional administration. The TI were registered as research and technology associations. This type of cooperation allowed the incorporation of additional companies in the TI and enabled them to have control in their management.

Some of the aims of Valencia TI were similar to the objectives of the Italian RSC: to supply innovative technology services to regional SME to compensate for their scarcity and lack of variety in the region. However, there are also some important differences related mainly to their strategic governance. The first RSC built on a successful training activity, and centres began to be established without any analysis of the specific needs of district firms (Brusco \& Pezzini, 1992; 2008). The network of RSC in Emilia Romagna was based on general requirements, which explains the breadth of the services they offered which contrasts starkly to their scarce resources. ${ }^{9}$ This implies that theorizing the ERVET model occurred a posteriori rather than being the result of planning, as it might be deduced from the work of some scholars (Bellini, 1990; Bellini, Giordani \& Pasquini,

\footnotetext{
${ }^{7}$ IMPIVA was responsible of the setting up of four Business Innovation Centres (BICs) and a technology park. We focus on TI since they are more similar to the Italian RSC.

${ }^{8}$ The initial TI network consisted of one institute related to shoes (INESCOP) and a few technology support units related to wood and furniture (Tecmade) and ceramics and tiles (Ceramics Technical Institute, University of Valencia).

${ }^{9}$ Available data show that, in the 1980s, 11 ERVET centres employed a total of 105 workers, i.e., an average of 10 per centre, which makes it unlikely that they were able to offer an effective service in an extensive industrial area such as Emilia-Romagna.
} 
1990; Bianchi \& Gualtieri, 1990; Leonardi \& Nanetti, 1990; Mazzonis, 1996; Capecchi, 1992; Cooke, 1996; Bellini \& Pasquini, 1998). ${ }^{10}$

On the other hand, the IMPIVA network of TI and their services were developed in line with a clear governance strategy and were managed by boards whose membership included firm representatives whose experience was gained through learning by doing. Operationalization of the IMPIVA network of TI was facilitated by dialogue with firms, close relationships with employers' associations and decentralized management. The process in each sector began with previous dialogue between IMPIVA and the presidents of sectoral employers' associations. Once preliminary agreement was reached about the need for a particular sector, an association of innovative companies was established for each field, with the assistance of the IMPIVA. Although the management boards of these associations included two representatives of the agency, they were most led by representatives from the leading innovative companies in each sector. The associations and IMPIVA together elected the director of the sector TI, which helped to provide management continuity and accumulation of experience and absorption of corporate knowledge.

The geographic agglomeration of firms in manufacturing clusters such as footwear, toys, ceramics, furniture and textiles resulted in the respective TI headquarters being located close to the cluster. Other TI provided business services to more distributed industries, such as metal-mechanical, plastic or food and beverages. A third group of TI responded to more general needs, through 'horizontal' centres such as optics and packaging. The

\footnotetext{
10 Belussi (2003: 246) suggests the impact of policies related to the provision of 'real' services has been exaggerated; he agrees with Brusco \& Pezzini (2008) that intermediate institutions, such as service centres, have fulfilled a learning centre role for their members, but even in these cases the institutions were established without a clear agenda.
} 
Valencian universities provided a fourth type after the transformation of academic units of research, with a substantial industrial effect (biomechanics, computation and energy), into TI

IMPIVA network of TI is considered a policy success because of the broad range and quality of the services provided and the collaboration with and within firms. This success was confirmed by firms through various opinion polls conducted by IMPIVA on users' satisfaction. The indicators provided in Mas et al. (1990) demonstrate the success of the early implementation of the IMPIVA network: in 1990, the existing eight institutes (average age 4.3 years) in the network had 1,353 affiliates, and had produced 7,675 laboratory analyses and 829 technical assessment services. The prestige of the TI has resulted in their representatives being used as expert advisers to the Spanish government.

The success of the TI and IMPIVA is attributed to their modern management practices based on efficient administration and transparency. Important for the management of TI was the introduction of contracts and privacy agreements to increase trust in the relationships with industry. Policies related to the price of the services provided help to identify demand and adapt them accordingly. IMPIVA set specific goals for the TI, but favoured interaction rather than hierarchical management and relationship with TI.

The economic relationship between IMPIVA and the TI initially depended on annual funding for the TI's projects. IMPIVA evaluated the projects proposed based on objective criteria (e.g. number of associated companies, total volume of sales or human resources costs relative to total spend), to promote the most efficient use of staff. The agency took account of changes that required improvements to or expansion of specific services. Regular meetings with TI presidents and representatives and their presence on the Advisory Board of IMPIVA, up to 1995, enabled good relationships and mutual understanding of the possibilities and constraints that applied to both parties. The 
relationships between companies and IMPIVA (and indirectly, also with the TI) were improved as a result of the implementation of regional programmes to support the development of technological innovation, the modernization of industrial equipment, and the promotion of design and fashion. For example, to encourage design efforts, a congress was held in 1985 which proposed scholarships for stays in main international academies and schools of design; IMPIVA also set up a design library and documentary unit at its headquarters, to improve relationships with and among designers; and several design units were set up in TI in line with IMPIVA's decentralization strategy. This strategy is also evident in initiatives such as the setting up of independent technical units close to regional mini-clusters.

\section{Changes to innovation policy strategies and differential survival of public provision of innovation services in Emilia-Romagna and Valencia.}

In the 1990s the innovation strategies in both the Spanish and Italian regions changed. In Emilia-Romagna, in the early 1990s and coinciding with the period of political change in regional institutions (1990), ERVET underwent thorough review and assessment of the public support it provided to firms and its supposed unfair competition for private firms belonging to sectors of technological and related services. This review was the result of lobbying by the employer's associations attached to large firms (Rinaldi, 2005; Mazzonis, 1996), but also served the interests of other business associations. It was hoped that reducing ERVET's influence would increase the spread of a 'free market' and allow new services to be offered by associations of employers. This lobbying effort coincided with regional budget constraints and had consequences for some nodes in the 
RSC network, which either disappeared or was forced to accept the reduced public financial support.11

The reorientation of RSC was a result also of the large number of centres that had been established and their original rather ambitious goals, which were out of kilter with the available resources (see Table 2). Among the 11 IMPIVA TI for which data are available, in the 1990s, the number of employed staff was 420 researchers, engineers and support staff (Ors, 1994) compared to around 103 people in the RSC between 1988 and 1995 (Bellini \& Pasquini, 1998). Some ten years later (circa 2005), the respective figures were 1,328 and 221 (Maccani, 2007), highlighting the different expansion and implementation of ERVET and IMPIVA networks. At the same time, industrial production in the Italian region in 2005 was double that in Valencia. Under these conditions, the scarce resources of the RSC could hardly develop an effective policy. This profound change calls into question the robustness attributed to Emilian institutional model (Cooke \& Morgan, 1998).

The reform of ERVET passed by government in 1993 led to a reduction in its responsibilities and resources. The RSC made efforts to adapt to the new framework and new competition rules and offer its services to medium-sized and large regional companies and to firms located in other Italian regions. However, some of the provisions of the new regional law were not fulfilled, such as the functions attributed to ERVET for the creation of scientific and technological nodes, technology transfer and economic

\footnotetext{
11 Note that Brusco (1993) suggests that government intervention was limited to about 5 years and proposed the introduction of user fees to contribute to the self-financing of the RSC. There were also other reasons for the crisis in ERVET related to changes in the regional economy that occurred in the 1980s and the emergence of new business hierarchies that replaced the traditional SME in relation to their size and marketing and management skills (Bellini \& Pasquini 1998).
} 
profiting from research, functions that were assumed by ASTER (Agency for Technological Development of Emilia-Romagna), which had been created in 1985 and initially was part of ERVET. In 2003 there was a second reform that resulted in ERVET becoming a regional development agency responsible for (among other tasks) providing technical assistance to the region's infrastructure and attracting foreign investment, promoting cooperation with developing countries and developing collaborative activities with other European regions.

In the early 1990s, Valencia suffered a major economic crisis. The victory of the conservative (Popular) party in the 1995 regional elections threatened the prevailing policy. Since the implementation in 1983 of the new innovation policy, the top regional representatives of the main Spanish employers' association were opposed to IMPIVA, considering it interventionist, elitist and not focused on the problems being experienced by firms.12 They advocated for a more traditional industry policy incorporating grants, subsidies and low borrowing rates to encourage business investment, and other initiatives not linked to a specific innovation strategy. It could be argued that employers were trying to maintain a monopoly on the relationships between government and firms, which they saw as being threatened by firms having ties to regional government through TI.

However, the TI were intended to be governed by ad-hoc associations of firms interested in new services to facilitate innovation activities, and IMPIVA funded part of the investment needed for these activities through a combined bottom-up/ top-down/ process. The model of governance in 1995 supported a wide ranging relationship between firms’

\footnotetext{
12 Some initial opponents subsequently admitted to misunderstanding the rationale for this regional government policy: the terms technological innovation, product differentiation, design, trademark, quality and internationalization were ‘too’ new for many firms.
} 
sectoral associations and the TI. Some of these associations were able to buffer the activities of the conservative government and the higher representatives of the employers' association. It became clear that the network of TI would survive only with the support of the regional agency, otherwise it would sink because the employers' sectoral associations were not sufficiently strong to sustain it. As result, the new regional government decided to reduce only partially economic support to the TI but making future funding uncertain and promoting self-financing.

The bottom-up approach of the IMPIVA network of TI, which was a conscious strategy, enabled the network to resist some of the pressure to abandon the former innovation policy, resulting in a decoupling of industry policy from an ideological position that was likely to damage cooperation among IMPIVA, firms and the TI. This explains the lower levels of privatization and self-financing in Valencia than in Emilia-Romagna. On the other hand, Emilia-Romagna developed a strong mechanical sector that requires high levels of technological expertise, which has encouraged the development of advanced services in private firms while the technology requirement for Valencia’s manufacturing sectors and specialization of advanced services, like those intensive in knowledge, is much lower, supporting continuity of the TI.

Finally, we discuss the consequences of policy changes in Emilia-Romagna and Valencia and the effects of a shift towards more self-financing of the RSC and TI after the crisis in the mid-1990s. First, both organizations began to force closer relationships with large companies. This was not a retrograde step because it can lead to the acquisition of new expertise; however, it is counterproductive if it increases the likelihood of smaller firms being excluded due to the higher transaction costs involved in providing innovative and non-standardized services. Second, the TI service centres began to focus on low risk projects, a strategy that had three major consequences. First, an emphasis on projects 
funded by European programmes, which were low risk, provided the possibility of more certain finance in the long term, and opportunities for international relationships and contacts with new sources of knowledge. Second, it became more difficult to develop collaborative regional projects involving several centres, which required long term commitment or investment in new infrastructure, because of the higher risks and higher implementation and transaction costs. Third, the scarce provision of new, specialised and risky new services because, also according to the new criterion, they have not demand enough to justify their implementation, confronted with well-known and standardized services, more efficient from this point of view (Bellini 2002).

In IMPIVA's case, there was a loss of 'freshness' in the relationships among network nodes. Even moderation of regional-government positions after an initial hostile reception, did not prevent some loss of IMPIVA's leadership. An indirect example is the creation by the TI of a lobby to defend their positions before IMPIVA and Spanish public administration.

\section{Conclusions}

The paper contrasted innovation policy in Emilia-Romagna and Valencia. Both regions have several similar economic and demographic features, including their industrialization processes, high proportion of SME, specialization in traditional manufacturing, concentration of firms in industrial districts and export activity.

They both introduced innovative policy tools targeting SME, such as RSC (EmiliaRomagna) and TI (Valencia) in an attempt to overcome the barriers to providing advanced technological services to these firms. However, implementation and policy development followed different paths and were of different intensity due to the 
differences between the institutional and governance models of these regions and resulting greater strength of Valencia’s policy.

In the 1990s, both regional governments revised their policies with the aim of reducing the public interventionism. The result was higher levels of privatization and selffinancing in Emilia-Romagna than in Valencia. In the Italian region, the absence of an initial and persistent strategy, the presence of different employers' associations with their own networks of firm services, the development of a private sector for advanced services, regional budget constraints, the small size of most RSC and the political changes since 1989 exerted strong pressure against regional policy. The result was an abrupt switch towards privatization of the services previously offered by ERVET and deep transformation of this agency.

In Valencia, the conscious choice of bottom-up governance supported a closer relationship between IMPIVA and firms' sectoral associations and innovative SME, which favoured the survival of the TI even in the difficult economic and political conditions of mid 1990s. Also, features of IMPIVA's original policies had an impact, for example, the holistic conception of its programmes, which allowed for synergies between TI and companies, and territorial decentralization of its innovation policies. There were also factors such as appropriate budget, small development of private firms in the field of knowledge services and the scale economies achieved by TI. All this aspects contributed to strengthening policy which helped SME and created a new and positive image of regional industry. However, the reduction in public funding had some negative consequences for the SME in both regions by encouraging lower risk service provision, priority being given to large companies’ needs, and extra-regional projects designed to ensure continuity of the TI and RSC. 
An industry innovation policy for SME, that is strong enough to survive the turmoil of political and economic changes needs an appropriate level of public governance that is not overly bureaucratic and is oriented to cognitive and territorial proximity to the policy recipients. This does not imply inertia or suggest that there is no need for evaluations and modifications to policy. Current problems are different from those in the 1980s and 1990s and policy must be adapted to reflect the new challenges. At the same time, policy takes time to achieve its objectives (Steinberg, 2012). We believe this comparative study of the Emilia-Romagna and Valencian cases provides some interesting lessons for scholars and policy makers keen to understand and achieve this subtle equilibrium between institutional continuity and adaptation to change. 


\section{References}

ALBORS-GARRIGÓS, J., SEGARRA, M., and RINCÓ-DÍAZ, C.A. (2010) Los Institutos Tecnológicos en el Sistema de Innovación Regional Valenciano. Propuesta de un modelo contingente de estrategia y desempeño, Dirección y Organización, 42, pp. 54-62.

AMIN, A. (1999) The Emilian model: Institutional challenges, European Planning Studies, 7 (4), pp. 389-405.

ANSELL, C. (2000) The networked polity: Regional development in Western Europe, Governance, 13 (3), pp. 303-333.

BARGE-GIL, A., and MODREGO, A. (2007) Los Centros Tecnológicos como instrumentos de intervención pública en los Sistemas Regionales de Innovación, in Vence, X. (eds) Crecimiento y políticas de innovación. Madrid: Editorial Pirámide, pp. 241-271.

BELUSSI, F. (1999) Policies for the development of knowledge-intensive local production systems, Cambridge Journal of Economics, 23 (6), pp. 729-747.

BELUSSI, F. (2003) The Italian system of innovation: the gradual transition from a weak 'mission-oriented' system to a regionalized learning system, in BIEGELBAUER and BORRÁS (Eds.) Innovation Policies in Europe and the US. The New Agenda. Aldershot: Ashgate.

BELLINI, N. (1990) The management of the economy in Emilia-Romagna: the PCI and the regional experience, in LEONARDI, R. and NANETTI, R. Y. (eds.) The Regions and European Integration. The Case of Emilia-Romagna. London: Pinter Publishers.

BELLINI, N. (1996) Regional Economic Policies and the Non-Linearity of History, European Planning Studies, 4 (1), pp. 63-73.

BELlinI, N. (2002) Business Support Services. Marketing and the Practice of Regional Innovation Policy. Cork: Oak Tree Press.

BELLINI, N., GIORDANI, M. G. and PASQUINI, F. (1990) The industrial policy of Emilia-Romagna: the business service centres in LEONARDI, R. and NANETTI, R. Y. (eds.) The Regions and European Integration. The Case of EmiliaRomagna. London: Pinter Publishers.

BELLINI, N., MOHAMMAD-SAÏD, D, and NÉGRIER E. (1996) Politique industrielle en Émilie-Romagne: Un modèle en quête de son avenir, Pôle Sud, 5, pp. 117:131.

BELLINI, N. and PASQUINI, F. (1998) The Case of ERVET in Emilia-Romagna. Towards a Second-Generation Regional Development Agency, in HALKIER, H., DANSON, M. and DAMBORG, C. (eds.) Regional Development Agencies in Europe. London: Jessica Kinsgley Publishers and Regional Studies Association.

BIANCHI, P. (1992) Levels of policy and the post-fordist competition in STORPER, M. and SCOTT, A.J., Pathways to Industrialization and Regional Development. London: Routledge.

BIANCHI, P. (1995) Nuevo enfoque en el diseño de políticas para las pymes. Aprendiendo de la experiencia europea. Buenos Aires: Documento de Trabajo 72, CEPAL, Comisión Económica para América Latina y el Caribe.

BIANCHI, G. (1998) Requiem for the Third Italy? Rise and fall of a too successful concept, Entrepreneurship \& Regional Development, 10 (2), pp. 93-116.

BIANCHI, P., and GUALTIERI, G. (1990) Emilia-Romagna and its industrial districts: the evolution of a model, in LEONARDI, R. and NANETTI, R. Y. (eds.) The 
Regions and European Integration. The Case of Emilia-Romagna. London: Pinter Publishers.

BIANCHI, P., and BELLINI, N. (1991) Public policies for local networks of innovators, Research Policy, 20 (5), pp. 487-497.

BIANCHI, P., and GIORDANI, M.G. (1993) Innovation policy at the local and national levels: The case of Emilia-Romagna, European Planning Studies, 1 (1), pp. 2541.

BIANCHI, P., and SANDRINE, L. (2011) Industrial policy after the crisis: the case of the Emilia-Romagna region in Italy, Policy Studies, 32:4, pp. 429-445.

BOIX, R., and GALLETTO, V. (2006a) El mapa de los distritos industriales de España, Economía Industrial, 359, pp. 95-112.

BOIX, R. and GALLETTO, V. (2006b) Sistemas locales de trabajo y distritos industriales marshallianos en España, Economía Industrial, 359, pp. 165-184.

BRUSCO, S. (1982) The Emilian model: productive decentralisation and social integration, Cambridge Journal of Economics 6, pp. 167-184.

BRUSCO, S. (1989) Piccole imprese e distretti industriali. Una raccolta di saggi. Torino: Rosenberg \& Sellier.

BRUSCO, S. (1992) The idea of the industrial district: Its genesis, in PYKE, F., BECATTINI, G. and SENGENBERGER, W. (Eds.) Industrial Districts and Inter-firm Cooperation in Italy. Geneva: ILO.

BRUSCO, S. (1993) Pequeñas empresas y prestación de servicios reales, in PYKE, F. and SENGENBERGER, W.: Los distritos industriales y las pequeñas empresas III. Distritos industriales y regeneración económica local. Madrid: Ministerio de Trabajo y Seguridad Social.

BRUSCO, S. and PEZZINI, M. (1992) Small-scale enterprise in the ideology of the Italian left, in in PYKE, F., BECATTINI, G. and SENGENBERGER, W. (Eds.) Industrial Districts and Inter-firm Cooperation in Italy. Geneva: ILO.

BRUSCO, S. and PEZZINI, M. (2008) La piccola impresa nell'ideologia della sinistra in Italia, in BRUSCO, S. (ed.): I distretti industriali: lezioni per lo sviluppo. Una lettera e nove saggi (1990-2002). Bologna: Il Mulino.

CAPECCHI, V. (1992) A history of flexible specialisation and industrial districts in Emilia-Rornagna, in PYKE, F., BECATTINI, G. and SENGENBERGER, W. (Eds.) Industrial Districts and Inter-firm Cooperation in Italy. Geneva: ILO.

COOKE, P. (1996) Building a twenty-first century regional economy in EmiliaRomagna, European Planning Studies, 4(1), pp. 53-62.

COOKE, P., and MORGAN, K. (1994) Growth Regions under Duress: Renewal Strategies in Baden-Württemberg and Emilia-Romagna, in AMIN, A. and Thrift, N. (eds), Globalisation, Institutions, and Regional Development in Europe. New York: Oxford University Press, pp. 112-113.

COOKE, P., MORGAN, K. (1998) The Associational Economy. Firms, regions and innovation. Oxford: Oxford University Press.

COWELL, M. (2010) Polycentric Regions: Comparing Complementarity and Institutional Governance in the San Francisco Bay Area, the Randstad and Emilia-Romagna, Urban Studies, 47(5), pp. 945-965.

ERVET (2002) ERVET S.p.A. The Emilia-Romagna Development Agency (mimeo).

ESTEVE, S., MARTÍNEZ-SERRANO, J.A., and PICAZO, A.J. (2000) Industria y desarrollo tecnológico en la Comunidad Valenciana, Economía Industrial, 335/336, pp. 315-328. 
FERNÁNDEZ DE LUCIO, I., ROJO, J., and CASTRO, E., (2003) Enfoque de Políticas Regionales de Innovación en la Unión Europea. Madrid, Academia Europea de Ciencias y Artes.

GARCÍA-QUEVEDO, J., and MAS-VERDU, F. (2008) Does only size matter in the use of knowledge intensive services?, Small Business Economics 31 (2), pp. 137146.

GARCÍA-RECHE, A. (Ed.) (2003) Política económica estructural y de competitividad. Valencia: Tirant Lo Blanch.

GARCÍA-RECHE, A and PICAZO-TADEO, A. (2007) What makes environmental performance differ between firms? Empirical evidence from the Spanish tile industry, Environment and Planning A 39, pp. 2,232-2,247.

HEINDEREICH, M. (1996) Beyond flexible specialization: The rearrangement of regional production orders in Emilia-Romagna and Baden-Württemberg, European Planning Studies, 4 (4), pp. 401-419.

HOLMSTRÖM, M. (1999) Employment in Smaller Indian Firms: Choices under Liberalisation, Economic and Political Weekly, 34 (39), pp. L2-L9.

HOLMSTRÖM, M. (2006) Globalisation and Good Work: IMPIVA, a Spanish Project to Regenerate Industrial Districts, Tijdschrift voor economische en sociale geografie, 97 (5), pp. 491-502.

HUGHES, E. C. (1936) The Ecological Aspect of Institutions. American Sociological Review, 1, pp. 180-189.

KRISTENSEN, P. H. (1992) Industrial Districts in West Jutland, Denmark, in PYKE, F. and SENGEBERGER, W. (eds.) Industrial Districts and local economic regeneration. Geneva: International Institute for Labour Studies.

LEONARDI, R. and NANETTI, R.Y. (1990) Emilia-Romagna and Europe: a case study of regional transformation in preparation for the Single Market, in LEONARDI, R. and NANETTI, R. Y. (eds.) The Regions and European Integration. The Case of Emilia-Romagna, London: Pinter Publishers.LIGABUE, L. (1995) Creation d'un centre de service reel: l'experience italienne. ONUDI http://www.unido.org/fileadmin/import/userfiles/russof/liga.pdf. $\quad$ Accessed 20.08.2012.

LÓPEZ-ESTORNELL, M. (2007) Experiencias de éxito en políticas regionales relacionadas con la Innovación, Estudio piloto sobre Emilia-Romagna. Valencia: Instituto de Gestión de la Innovación y el Conocimiento-INGENIO (CSIC-UPV), mimeo.

LÓPEZ-ESTORNELL, M. (2010) Empresa innovadora, conocimiento y distrito industrial. Valencia: Doctoral Theses, Universidad Politècnica de València.

LÓPEZ-ESTORNELL, M., MAS-VERDÚ, F. and MOLINA F.X. (2008) Política tecnológica aplicada a los distritos industriales in Mediterráneo Económico, 13, pp. 435-458.

MACCANI, P. (2007) The role of a regional development agency in the improvement of regional territorial policies.

http://www.dps.tesoro.it/cd_cooperazione_bilaterale/docs/3.Development_Tools/ 1.Best_practices/1.role_RDA_improv_reg_territ_pol_maccani.pdf. . Accessed 20.08.2012.

MACCANI, P., and SAMOGGIA, A. (2010) Multilevel Governance and the Role of Regional Agencies in Territorial and Rural Development. A Snapshot of Three European Countries in RAMÍREZ, L., KEBEDE, G. Strategic Planning for Local Development. Case Studies from Small and Mid-Sized European Cities. Belgrade: UN-HABITAT SIRP. 
MARTINEZ-GOMEZ, V., BAVIERA-PUIGA, A. and MAS-VERDU, F. (2010) Innovation policy, services and internationalization: the role of technology centres, The Service Industries Journal 30 (1), pp. 43-54

MAS-VERDU, F. (2007) Services and Innovation Systems: European Models of Technology Centres, Service Business 1 (1), pp. 7-23.

MAS-VERDÚ, F., BAVIERA-PUIG, A., and MARTÍNEZ-GÓMEZ, V. (2008) Internacionalización, servicios y política de innovación: El papel de los Centros Tecnológicos, ICE, 844, pp. 155-165.

MAS, F., RICO, A., and MAFE, J. (1990) Política industrial y modelos de organización, Economía Industrial, pp. 61-72.

MAZZONIS, D. (1996) The changing role of ERVET in Emilia-Romagna, in COSSENTINO, F., PYKE, F. and SENGENBERGER, W. Local and regional response to global pressure: The case of Italy and its industrial districts. Geneva: International Institute for Labour Studies.

MONTERO, A. P. (2001) Delegative Dilemmas and Horizontal Logics: Subnational Industrial Policy in Spain and Brazil, Studies in Comparative International Development, 36 (3), pp. 58-89.

MORENO, M. D. (1993) Training and the implementation of quality programmes by a sample of small and medium-sized firms in Spain, The International Journal of Quality \& Reliability Management, 10 (3), pp. 6-19.

MUÑOZ, A. (2009) La información para la empresa y el sistema de I+D+i. El caso de la región valenciana, Revista General de Información y Documentación, 19 (1), 121-144.

ORS, J. (1994) Small firm innovation networks in the Valencia Region, European Planning Studies, 2 (2), pp. 207-221.

PETRAKOS, G.C. (1996) Small Enterprise Development and Regional Policy Comparative Analysis and Implications for Central and East European Countries, Eastern European Economics, 34 (2), pp. 31-64.

PIETROBELLI, C., and RABELLOTI, R. (2002) Business development service centres in Italy. An empirical analysis of three regional experiences: Emilia Romagna, Lombardia and Veneto. Santiago de Chile: CEPAL, Serie Desarrollo Productivo, n. 130.

PONCE, G. (2004) ¿Cambio tecnológico o aumento de la competitividad? Las políticas de innovación industrial en la Comunidad Valenciana, Ería, 63, pp. 91-106.

RICO, A. (Coor.) (1982) L’economia del País Valencià: Estratègies sectorials. València: Alfons el Magnànim,.

RINALDI, A. (2005) The Emilian Model Revisited: Twenty Years After, Business History, 47 (2), pp. 244-266.

SALOM-CARRASCO, J. (1997) Política industrial de apoyo a la innovación en áreas de desarrollo endógeno: El caso de la Comunidad Valenciana a la luz de las experiencias europeas recientes, Cuadernos de Geografía, 61, pp. 145-154.

SAMOILOVICH, D. et al. (2005) Instituciones de apoyo a la tecnología y estrategias regionales basadas en la innovación. Buenos Aires: Oficina de la CEPAL.

SLEIGH, STEPHEN R. (ed.) (1993) Economic Restructuring and Emerging Patterns of Industrial Relations. Kalamazoo, MI: W.E. Upjohn Institute for Employment Research.

SOLARI, S. (2004) Decentralisation of Competencies and Local Development Agencies in North-Eastern Italy, Local Economy, 19 (1), pp. 55-68. 
STEINBERG, P. F. (2012) Welcome to the Jungle: Policy Theory and Political Instability, forthcoming in STEINBERG, P.F. and VANDEVEER, S.D., (Eds.) Comparative Environmental Politics. MA: MIT Press.

TOMÁS, J.A., CONTRERAS J.L., and Del SAZ, S. (2000) Institutos tecnológicos y política sectorial en distritos industriales: el caso del calzado, Economía Industrial, 334, pp. 25-34.

\section{Annexe}

Emilia-Romagna, Regional Government of Emilia-Romagna (3), CNA Innovazione, ASTER, Confindustria, UNIONAPI Emilia-Romagna, Unioncamere, ASTER, Comunidad Valenciana Foundation, IRPET, University of Firenze, IMPIVA (3), Universitat de València, Universitat Politècnica de València. 


\section{Tables}

\begin{tabular}{|l|l|l|}
\hline Table 1 Statistics for Emilia-Romagna and Valencia \\
\hline & $\begin{array}{c}\text { Emilia- } \\
\text { Romagn } \\
\text { a }\end{array}$ & Valencia \\
\hline Regional capital & Bologna & Valencia \\
\hline Surface (km2) & 22,125 & 23,254 \\
\hline Population (2005, ER; 2006, V) & $4,187,557$ & $4,806,908$ \\
\hline $\begin{array}{l}\text { Regional population as of national } \\
\text { population }\end{array}$ & 7.1 & 10.8 \\
\hline Population density (no. of inhabitants/km2) & 191 & 207 \\
\hline Number of municipalities & 341 & 542 \\
\hline Population: main regional city & 380,000 & 934,000 \\
\hline $\begin{array}{l}\text { Population: main regional city + metropolitan } \\
\text { area }\end{array}$ & 934,000 & $1,500,000$ \\
\hline Population of other main cities $\left.*^{*}\right)$ & $98,400-170,000$ & $172,000-322,000$ \\
\hline Number of provinces & 9 & 3 \\
\hline $\begin{array}{l}\text { Main regional transport axis } \\
\text { Coastline (km approx.) }\end{array}$ & Via Emilia & Highway \\
\hline $\begin{array}{l}\text { Per capita GDP (European Union=100) } \\
\text { PPP, 2004 }\end{array}$ & 100 & 500 \\
\hline$(*) 172,000-541,000$ if the urban area Alicante-Elche is considered \\
\hline Source: Own elaboration & 130 & 94 \\
\hline
\end{tabular}




\begin{tabular}{|c|c|c|c|c|c|c|c|c|c|c|c|c|}
\hline \multicolumn{13}{|c|}{ 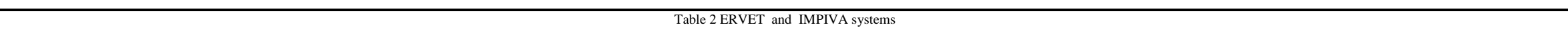 } \\
\hline Centre & Sector/activity & $\begin{array}{l}\text { Setting } \\
\text { up year }\end{array}$ & $\begin{array}{c}\text { \% ERVET } \\
\text { participation (1995) }\end{array}$ & $\begin{array}{l}\text { Employees } \\
\text { (1) }\end{array}$ & $\begin{array}{l}\text { Employees c. } \\
2005\end{array}$ & $\begin{array}{l}\text { Currently part of } \\
\text { ERVET network }\end{array}$ & Centre & Sector/activity & $\begin{array}{l}\text { Setting } \\
\text { up year }\end{array}$ & $\begin{array}{c}\text { Employees c. } \\
1991\end{array}$ & $\begin{array}{l}\text { Employees c. } \\
2006\end{array}$ & $\begin{array}{c}\text { Currently part of } \\
\text { IMPIVA } \\
\text { network }\end{array}$ \\
\hline \multicolumn{13}{|c|}{ Sectoral Services Centres or IT } \\
\hline CITER & Textile & 1980 & 25 & $19^{*}$ & 12 & $\bar{x}$ & $\operatorname{INESCOP}(1)$ & Footwear & 1984 & 76 & 118 & $\mathrm{x}$ \\
\hline CESMA & Agrarian Machinery & 1983 & 40 & $4^{*}$ & 3 & & AICE (2) & Ceramics & 1984 & 56 & 129 & $\mathrm{X}$ \\
\hline CERCAL & Footwear & 1983 & 46,7 & $6^{*}$ & 5 & & AIDIMA (3) & Furniture & 1984 & 35 & 111 & $\mathrm{x}$ \\
\hline QUASCO & Building & 1985 & 44,1 & $11^{*}$ & 17 & $\mathrm{x}$ & AITEX & Textile & 1985 & 35 & 99 & $\mathrm{x}$ \\
\hline Centro Ceramico & Ceramics & 1976 & na & $31^{* *}$ & 38 & & AIJU & Toys & 1985 & 29 & 59 & $\mathrm{x}$ \\
\hline \multirow[t]{5}{*}{ CEMOTER } & $\begin{array}{l}\text { Land-transporting } \\
\text { Machinery }\end{array}$ & 1982 & na & $13^{* *}$ & & & AIMME & Metal-Mechanics & 1987 & 72 & 87 & $\mathrm{x}$ \\
\hline & & & & & & & AINIA & Food & 1987 & 43 & 163 & $\mathrm{X}$ \\
\hline & & & & & & & AIDICO & Building & 1990 & 10 & 99 & $\mathrm{X}$ \\
\hline & & & & & & & AIMPLAS & Plastics & 1990 & 10 & 71 & $\mathrm{X}$ \\
\hline & & & & & & & ALICER $(* * *)$ & Ceramics design & 1993 & na & na & $\mathrm{X}$ \\
\hline \multicolumn{13}{|c|}{ Horizontal Services Centres or IT } \\
\hline ASTER & Technological Development & 1985 & 64 & $11^{* *}$ & 30 & & IBV (4) & Biomechanics & 1986 & 38 & 137 & $\mathrm{X}$ \\
\hline CERMET & Metal-Mechanics & 1985 & 32,2 & $8^{* *}$ & 90 & $\mathrm{X}$ & ITENE & Packaging & 1993 & na & 73 & $\mathrm{X}$ \\
\hline \multirow[t]{3}{*}{ DEMOCENTER } & Industrial Automatization & 1991 & 29,2 & & 26 & & ITI (4) & ITC & 1994 & na & 47 & $\mathrm{x}$ \\
\hline & & & & & & & ITE (4) & \begin{tabular}{|l|l} 
Energy \\
\end{tabular} & 1994 & na & 62 & $\mathrm{x}$ \\
\hline & & & & & & & AIDO (4) & Optics & 1986 & 16 & 73 & $\mathrm{X}$ \\
\hline \multicolumn{13}{|c|}{ Financial Services } \\
\hline FIT & $\begin{array}{c}\text { Financiation for } \\
\text { Technological Development }\end{array}$ & & 75,3 & & & & & & & & & \\
\hline \multicolumn{13}{|c|}{$\begin{array}{l}\text { In } 1995 \text { are no longer linked to ERVET: SVEX (export promotion), ASE (local development agency in Ravenna), PROMORESTAURO (promotion of historical and artistic heritage in Bologna), Rosalind (industrial promotion in Piacenza), IDROSER (water resources for } \\
\text { development of the region), CETAS (training of experts in food and agriculture in developing countries), SPOT (Promotion and transfer of services to improve the metal-mechanic industry) and RESFOR (outsourcing of machinery) }\end{array}$} \\
\hline
\end{tabular}

